\title{
Sex-specific temperature distribution in four populations of American plaice Hippoglossoides platessoides
}

\author{
D. P. Swain ${ }^{1, *}$, M. J. Morgan ${ }^{2}$ \\ ${ }^{1}$ Department of Fisheries and Oceans, Gulf Fisheries Centre, PO Box 5030, Moncton, New Brunswick E1C 9B6, Canada \\ ${ }^{2}$ Department of Fisheries and Oceans, PO Box 5667, St. John's, Newfoundland A1C 5X1, Canada
}

\begin{abstract}
In the American plaice Hippoglossoides platessoides, the sexes differ in size at age in most populations, with females being larger. Because of the links between growth, ration and temperature, differences in temperature selection might be expected between the sexes in species with dimorphic growth, with the sex with the higher growth rate selecting higher temperatures. Temperature selection has also been predicted to be density-dependent in fishes, with fish occupying colder temperatures at higher levels of abundance. We examined these aspects of temperature selection in 4 populations of American plaice: the southern Gulf of St. Lawrence population and 3 populations off Newfoundland (Labrador and NE Newfoundland, Grand Bank and St. Pierre Bank). Throughout the 1970 s and most of the 1980s plaice occupied cold water relative to that available in all of the areas surveyed. In all 4 populations, females tended to occupy warmer water than males. Differences between the sexes in temperature selection and in length at age both tended to be greatest in the southern Gulf population during this period. However, there was no correspondence among populations in these differences in the early 1990s, when distribution of the Grand Bank and St. Pierre Bank populations shifted sharply into warm water and the difference in temperature distribution between the sexes increased dramatically in these populations. These shifts to warmer water may be related to density-dependent effects on temperature preference. There was a strong negative relationship between the temperatures occupied by plaice and their relative abundance in the 3 Newfoundland populations but not in the southern Gulf population. Densities appear to have remained higher in the southern Gulf population than in the Newfoundland populations, suggesting that density-dependent effects on temperature preference only occur when densities fall below some threshold level.
\end{abstract}

KEY WORDS: Temperature selection - Sexual dimorphism - Density-dependent $\cdot$ Environmental change $\cdot$ Hippoglossoides platessoides $\cdot$ American plaice

\section{INTRODUCTION}

Habitat selection by fishes depends on a variety of biotic and abiotic factors such as prey abundance, substrate, depth and temperature (Scott 1982, Rose \& Leggett 1989, Walsh 1992, Swain \& Morin 1997). Since fishes are ectotherms, temperature has a significant effect on physiological processes such as metabolism

*E-mail: swaind@dfo-mpo.gc.ca and growth (Brett 1971, Magnuson et al. 1979). This makes temperature one of the key determinants of habitat quality for fishes (Fry 1971, Reynolds \& Casterlin 1979). Numerous studies have demonstrated relationships between temperature and the distribution of fishes (Scott 1982, Mahon et al. 1984, Rose \& Leggett 1989, Morgan \& Brodie 1991, Swain 1997).

Temperature and amount of food interact in their effect on growth rate in fishes. The optimum temperature for growth depends on ration level. As ration levels are reduced the most efficient temperature for 
growth decreases, reflecting the lower metabolic costs at lower temperatures (Elliott 1975, Brett 1979, Woiwode \& Adelman 1991). Thus, temperature selection in fishes should be related to ration level. If fish select habitats that yield the highest growth rates, the selected temperature should decrease as food availability decreases (Javaid \& Anderson 1967, Wildhaber \& Crowder 1990, Morgan 1993, Swain \& Kramer 1995).

The American plaice Hippoglossoides platessoides is a commercial flatfish with a wide geographic distribution in the Northwest Atlantic, occurring from western Greenland to the Gulf of Maine (Scott \& Scott 1988). Like many flatfish species, the sexes differ in size at age in most populations, with females being larger (Bowering \& Brodie 1991). Because of the links between growth, ration and temperature, differences in temperature selection might be expected between the sexes in species with dimorphic growth. If differences in size at age between the sexes reflect a difference in foraging rate or food ration, then the optimum temperature for growth will be higher in the larger sex and this sex should occupy warmer temperatures. Swain (1997) found this to be the case for the southern Gulf of St. Lawrence population of American plaice. The difference in temperature distribution between the sexes in this population appeared to be associated with feeding. Females occupied warmer water than males in the summer when feeding (and growth) occurs, but there was no difference in temperature distribution between the sexes in the winter, when these fish do not feed (Swain et al. 1998).

These results for the southern Gulf population suggest the hypothesis that populations with a greater difference in growth between the sexes should also show a greater difference in temperature distribution between the sexes. This should be the case if differences in growth reflect differences in food ration. One purpose of this study was to test this hypothesis by comparing growth and temperature distributions among 4 populations of American plaice: the Labrador and northeast Newfoundland (referred to here as NE Newfoundland), Grand Bank, St. Pierre Bank and southern Gulf of St. Lawrence populations (Fig. 1). Temperature conditions are very different in these different areas (Drinkwater et al. 1999) and it is likely that the degree of sexual dimorphism in size at age varies among these populations. We examined the temperature distribution for each sex and population relative to that available in the habitat, tested for a difference in temperature distribution between the sexes for each population, determined whether the extent of sexual dimorphism in growth differs among the populations, and examined whether the differences between the sexes in temperature distribution are related to the extent of sexual dimorphism in growth.

A second prediction following from the interactions between temperature,
Fig. 1. Map of the study area, showing Northwest Atlantic Fisheries Organization (NAFO) divisions. Division names are shown for the areas occupied by the Hippoglossoides platessoides populations examined in this study. The stock areas are: NAFO Divisions $2 \mathrm{GHJ}$ and $3 \mathrm{~K}$ for the Labrador and NE Newfoundland population, 3LNO for the Grand Bank population, 3Ps for the St. Pierre Bank population, and $4 \mathrm{~T}$ for the southern Gulf of St. Lawrence population 
ration and growth is that temperature selection should be density-dependent in fishes, with fish occupying colder temperatures at higher levels of abundance (Swain \& Kramer 1995). This should be the case if ration levels decline at high abundance due to competition. Shifts in the distribution of cod in the southern Gulf of St. Lawrence were consistent with this prediction (Swain \& Kramer 1995, Swain 1999). In contrast, density-dependent changes in temperature selection by plaice in the southern Gulf were slight compared to those displayed by cod (Swain 1997). Swain \& Morin (1996) suggested that the distribution of plaice in the southern Gulf has been independent of their abundance because even the lowest observed abundance levels were relatively high. Plaice in the populations off Newfoundland appear to have declined to densities that are much lower than the minimum levels seen in the southern Gulf (Fig. 2). A second purpose of this study was to test for density-dependent shifts in temperature distribution of plaice over this wider range of densities.

\section{MATERIAL AND METHODS}

Data sources. Data are from annual bottom-trawl surveys conducted by the Department of Fisheries and Oceans. The areas surveyed for each Hippoglossoides platessoides stock are: (1) NAFO (Northwest Atlantic Fisheries Organization) Divisions 2J and 3K for the Labrador and northeast Newfoundland stock; (2) NAFO Divisions 3LNO for the Grand Bank stock; (3) NAFO Subdivision 3Ps for the St. Pierre Bank stock,

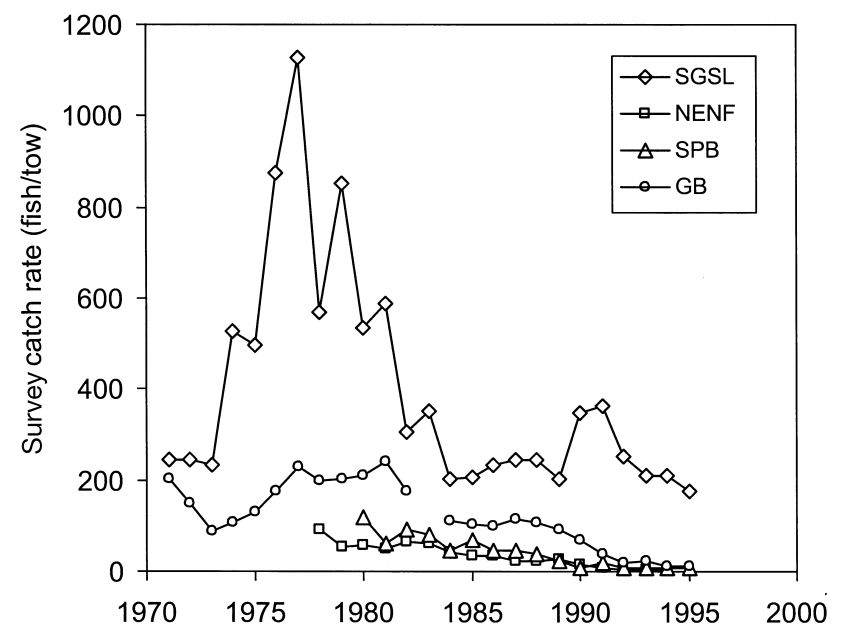

Fig. 2. Hippoglossoides platessoides. Mean catch rates of American plaice in bottom-trawl surveys in NAFO Divisions 2J3K (Labrador and NE Newfoundland, NENF), 3LNO (Grand Bank spring survey, GB), 3Ps (St. Pierre Bank, SPB) and $4 \mathrm{~T}$ (southern Gulf of St. Lawrence, SGSL) and (4) NAFO Division 4T for the southern Gulf of St. Lawrence stock (Fig. 1). All surveys followed a stratified random design, with stratification based on depth and geographic region (Doubleday 1981). Surveys of Divisions 3LNO and 3Ps were conducted by the 'A.T. Cameron' using a Yankee 41.5 otter trawl (1971-1982) and by the 'Wilfred Templeman' using an Engel 145 trawl (1983-1995). Surveys of Divisions 2J3K were conducted by the 'Gadus Atlantica' using an Engel 145 trawl in all years. Surveys of Division $4 \mathrm{~T}$ were conducted by the 'E. E. Prince' using a Yankee 36 trawl (1971-1985) or by the 'Lady Hammond' (1985-1991) or 'Alfred Needler' (1992-1996) using a Western IIA trawl. Surveys were conducted in September in $4 \mathrm{~T}$, in October to December in 2J3K, in April (1982-1984, 1993-1995) or February to March (1980, 1981, 1985-1992) in 3Ps, and in April to June (1971-1995) and September to December (1990-1994) in 3LNO. Sample sizes are shown in Table 1.

Comparative fishing experiments revealed a significant difference in fishing efficiency for plaice between the 'E. E. Prince' using a Yankee 36 trawl and the 'Lady Hammond' using a Western IIA trawl, but

Table 1. Numbers of tows in annual bottom-trawl surveys of NAFO areas 2J3K (Labrador and NE Newfoundland Shelf), 3LNO (Grand Bank), 3Ps (St. Pierre Bank) and 4T (southern Gulf of St. Lawrence). Tows without bottom temperature information have been omitted

\begin{tabular}{|c|c|c|c|c|c|}
\hline \multirow{2}{*}{ Year } & \multirow{2}{*}{$2 \mathrm{~J} 3 \mathrm{~K}$} & \multicolumn{2}{|c|}{ 3LNO } & \multirow{2}{*}{$3 \mathrm{Ps}$} & \multirow{2}{*}{$4 \mathrm{~T}$} \\
\hline & & Spring & Fall & & \\
\hline 1971 & & 84 & & & 66 \\
\hline 1972 & & 83 & & & 70 \\
\hline 1973 & & 128 & & & 70 \\
\hline 1974 & & 107 & & & 64 \\
\hline 1975 & & 113 & & & 66 \\
\hline 1976 & & 143 & & & 63 \\
\hline 1977 & & 190 & & & 61 \\
\hline 1978 & 125 & 267 & & & 62 \\
\hline 1979 & 127 & 333 & & & 74 \\
\hline 1980 & 134 & 255 & & 82 & 68 \\
\hline 1981 & 225 & 154 & & 61 & 67 \\
\hline 1982 & 304 & 242 & & 91 & 65 \\
\hline 1983 & 268 & & & 172 & 67 \\
\hline 1984 & 269 & 153 & & 94 & \\
\hline 1985 & 320 & 407 & & 122 & \\
\hline 1986 & 226 & 418 & & 149 & \\
\hline 1987 & 290 & 388 & & 144 & 125 \\
\hline 1988 & 294 & 316 & & 159 & 87 \\
\hline 1989 & 332 & 403 & & 153 & 165 \\
\hline 1990 & 344 & 341 & 376 & 114 & 140 \\
\hline 1991 & 346 & 365 & 385 & 172 & 188 \\
\hline 1992 & 327 & 374 & 306 & 152 & 152 \\
\hline 1993 & 286 & 349 & 313 & 140 & 177 \\
\hline 1994 & 277 & 320 & 348 & 181 & 150 \\
\hline 1995 & & 329 & & 172 & 174 \\
\hline 1996 & & & & & 194 \\
\hline
\end{tabular}


not between the 'Lady Hammond' and the 'Alfred Needler' (Nielsen 1994). This difference in fishing efficiency will not affect interannual comparisons of habitat associations, but will affect comparisons of relative abundance. For the analyses reported here, catches by the 'E. E. Prince' have been multiplied by 1.75 to make them equivalent to those by the 'Lady Hammond' and the 'Alfred Needler' (Nielsen 1994). There were also significant differences between the 'A.T. Cameron' and the 'Wilfred Templeman'. Catches by the 'A. T. Cameron' were multiplied by 0.5 for lengths less than $28 \mathrm{~cm}$ or by 1.3 for greater lengths to make them equivalent to those by the 'Wilfred Templeman' (Gavaris \& Brodie 1984). No comparisons are available between the Western IIA and Engel 145 trawls.

Growth. Lengths were measured by sex for each plaice catch. Otoliths were retained from a lengthstratified subsample of the catch for age determination. Age composition and length distributions at age were determined for each sex by applying division-wide age-length keys to the length distributions of each catch. For each stock, the stratified mean length at age was calculated for each sex. The difference between the sexes in these means was used as a measure of sexual dimorphism in growth. We restricted our analyses to Ages 4 to $12 \mathrm{yr}$, ages that were well represented in the survey catches for both sexes in all 4 populations over the time period studied.

Temperature distribution. For the $4 \mathrm{~T}$ area in all years and in the other areas from 1971 to 1989, nearbottom temperatures were obtained from hydrographic casts made after each trawl tow. Temperatures were obtained using reversing thermometers, mechanical bathythermographs and/or electronic probes. For the 2J3K, 3LNO and 3Ps areas since 1989, a trawlmounted Seabird-19 conductivity-temperature-depth probe was used to provide a horizontal average bottom temperature for each trawl tow. For each stock in each year, we calculated $T_{\mathrm{A}}$, the average temperature available to plaice within the survey area:

$$
T_{A}=\sum_{i=1}^{n} w_{i} x_{i}
$$

where $n$ is the number of tows in the survey, $x_{i}$ is the bottom temperature for tow $i$, and $w_{i}$ is the weighting factor associated with tow $i$. In most cases, $w_{i}$ is the proportion of the survey area in the stratum fished by tow $i$ divided by the number of sites fished in that stratum. In the 1987 and 1988 surveys in 4T, repeat tows were sometimes made at the same sites. For these 2 surveys, $w_{i}$ is the above quantity divided by the number of tows at the site fished by tow $i$. For each sex in each year and stock, we also calculated $T_{\mathrm{P}}$, the average temperature occupied by plaice:

$$
T_{p}=\sum_{i=1}^{n} w_{i} \frac{y_{i}}{\bar{Y}} X_{i}
$$

where $y_{i}$ is the number of plaice of that sex caught in tow $i$ and $\bar{Y}$ is the mean catch per tow (calculated using the weights $w_{i}$ ). We used the difference between the sexes in $T_{\mathrm{P}}$ as a measure of the difference in temperature distribution between the sexes.

Statistical analyses. We tested the significance of associations between plaice and temperature using randomization tests. We used the procedure described by Perry \& Smith (1994, p 592). The test statistic was the maximum difference between the cumulative distribution functions of temperature and of plaice catch in relation to temperature:

$$
\max _{\forall t} \mid \sum_{i} w_{i}\left(\frac{y_{i}-\bar{Y}}{\bar{Y}}\right) I\left(x_{i}\right) \text { where } I\left(x_{i}\right)= \begin{cases}1, & \text { if } x_{i} \leq t_{i} \\ 0, & \text { otherwise }\end{cases}
$$

where $t$ is an index of temperature, ranging from the lowest to the highest observed values. Each test was based on 2999 random permutations of the data (3000 permutations including the observed data). Each permutation was conducted by randomly pairing the catch weights $w_{i}\left[\left(y_{i}-\bar{Y}\right) / \bar{Y}\right]$ and the bottom temperature $x_{i}$ by sampling with replacement the observed $x_{i}$ with probability $w_{i}$.

We also tested the significance of the difference in temperature distribution between males and females using randomization tests. The test statistic was the average temperature occupied by females minus the average for males. The randomization procedure, conducted 2999 times, involved randomly redistributing plaice catches between males and females. For each tow, one of the observed catches was randomly assigned to males and the other to females.

Other tests involving interannual variation in temperature distribution or the difference between the sexes in occupied temperature or length at age were based on ANOVA or ANCOVA, calculated using the GLM procedure of SAS (SAS Institute Inc. 1990). We examined effects of environmental conditions and abundance on plaice temperature distribution using linear regression analysis, calculated using the REG procedure of SAS. We used the $\log _{e}$-transformed stratified mean catch per tow in a survey as a measure of relative abundance of plaice and the mean temperature available to plaice in the survey area as a measure of environmental conditions. A quadratic term for relative abundance was included in regression models to allow for the possibility, suggested by Swain \& Morin (1996), that effects of abundance on distribution may be stronger at lower levels of abundance. These regression analyses were conducted within populations because relative catchability was not known between surveys, particularly between the southern Gulf survey and the Newfoundland surveys. In these regression 
analyses, we tested for first-order autocorrelation using the Durbin-Watson test. Significant $(p<0.05)$ autocorrelation was detected in only 1 (NE Newfoundland females) of the 8 cases ( 2 sexes, 4 populations). For this case, we also fit a model with a first-order autoregressive term for the error using the AUTOREG procedure of SAS. The estimates of the autoregressive parameter did not differ significantly $(p>0.25)$ from zero, and other parameter estimates and their significance were similar to those in the ordinary linear model. Only the results for the ordinary linear regression models are presented below.

Measures of aggregation. The power of the randomization test for associations between plaice and temperature depends on the degree of aggregation in fish distribution (see Swain et al. 1998). A given value of the test statistic will be less significant according to these tests if fish are highly aggregated than if they are more evenly distributed. We used Lorenz curves (Dagum 1985) to examine variation in the degree of aggregation. To construct these curves we calculated the estimated percent of the population associated with each tow $i\left(N_{i}=100 w_{i} y_{i} / \bar{Y}\right)$ and the percent of the area associated with each tow $\left(A_{i}=100 W_{i}\right)$. We sorted the tows by $N_{i}$, and accumulated percent area along the abscissa and percent abundance along the ordinate. The resulting Lorenz curve becomes more concave as fish distribution becomes more aggregated or concentrated. We used the Gini index, twice the area between the Lorenz curve and the identity function, as an index of aggregation. Higher values of the index indicate greater aggregation.

\section{RESULTS}

\section{Plaice temperature associations}

The occurrence of Hippoglossoides platessoides was significantly related to temperature in all 4 populations (Fig. 3). Temperature associations were most frequently significant in spring surveys of the Grand Bank and in the NE Newfoundland Shelf surveys. Differences between the average temperatures occupied by plaice and those available to them tended to be greatest on St. Pierre Bank and in the southern Gulf of St. Lawrence, but these differences were less frequently statistically significant. This is partly the result of the lower sample sizes in the southern Gulf and St. Pierre Bank surveys (Table 1) and, for St. Pierre
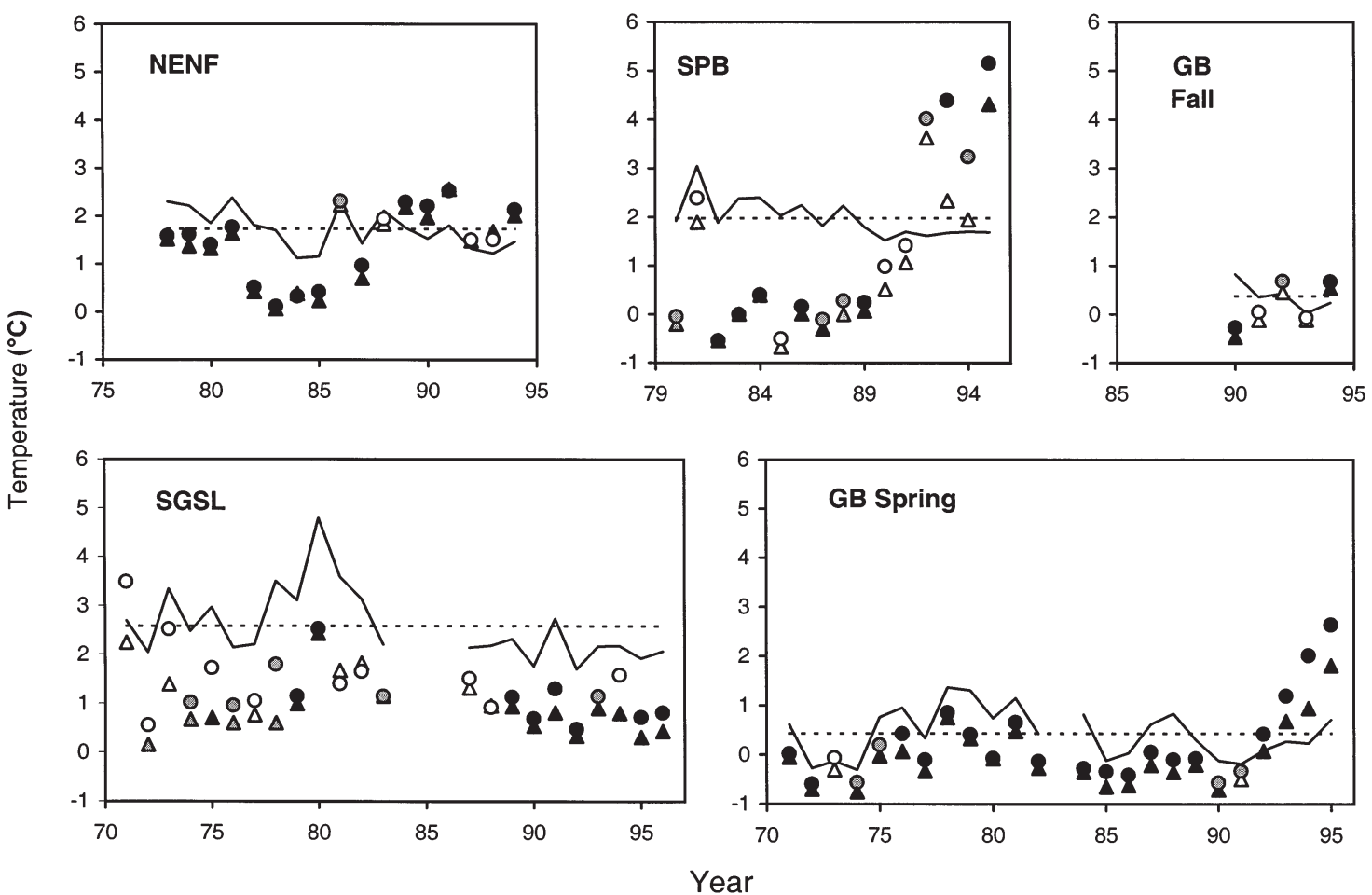

Fig. 3. Average temperatures occupied by plaice, Hippoglossoides platessoides, and available to them in the environment. Continuous line: temperature available; dashed line: average temperature available over the time period; $(\boldsymbol{\Delta}, \mathbf{\Lambda}, \Delta)$ males; $(\mathbf{0}, \boldsymbol{\bullet , 0})$ females; $(\boldsymbol{\Delta}, \boldsymbol{\bullet})$ significant association between plaice and temperature at $\mathrm{p}<0.01 ;(\Delta, 0)$ significant association $p<0.05) ;(\Delta, 0)$ no significant association. NENF: Labrador and NE Newfoundland; SPB: St. Pierre Bank; GB: Grand Bank; SGSL: southern Gulf of St. Lawrence 
Bank, the more highly aggregated nature of the fish (Table 2). Prior to the late 1980s or early 1990s, plaice in all 4 populations tended to occupy cold temperatures relative to those available in the survey areas. During this period, the average temperatures occupied by plaice tended to be coldest in the spring survey of the Grand Bank (mean $-0.11^{\circ} \mathrm{C}$ ), followed by the St. Pierre Bank survey (mean $0.12^{\circ} \mathrm{C}$ ) and the southern Gulf survey (mean $1.34^{\circ} \mathrm{C}$ ). Plaice in the NE Newfoundland area occupied temperatures that averaged 1.3 to $1.8^{\circ} \mathrm{C}$ in the 1978 to 1981 period and 0.1 to $0.5^{\circ} \mathrm{C}$ in the 1982 to 1985 period, below the average available in the survey area in both periods. However, from 1989, the average temperatures occupied by NE Newfoundland plaice were warmer than those available to them. Shifts in distribution toward warmer temperatures also occurred in the 1990s on St. Pierre Bank and on the Grand Bank in spring. These shifts were much more dramatic than those seen in the NE Newfoundland area, with the average temperatures occupied by plaice reaching levels 2 to $3.5^{\circ} \mathrm{C}$ above the average available to them in these areas in the mid-1990s. In contrast to the spring, plaice on the Grand Bank in the fall occupied temperatures near the average available to them throughout the 1990 to 1994 period. In the southern Gulf, plaice occupied temperatures significantly below the average available to them throughout this period.

\section{Difference in temperature distribution between the sexes}

Females tended to occupy warmer temperatures than males in all 4 populations (Fig. 4). This difference between the sexes was significant most frequently in the Grand Bank and southern Gulf populations and least frequently in the NE Newfoundland population. The magnitude of this difference tended to be greatest in the southern Gulf population, except in recent years. On the Grand Bank and on St. Pierre Bank in spring, the difference in temperature distribution between the sexes increased sharply in recent years, coincident with the shift in distribution to warmer waters in these areas. This difference between time periods (before and after 1990) was highly significant (Fig. 5; ANOVA: population $\times$ period interaction, $F_{3,72}=5.36, \mathrm{p}=0.002$ ) In the period prior to 1990 , the average temperature difference between the sexes was greatest in the southern Gulf population and similar among the other

Table 2. Hippoglossoides platessoides. Gini index of concentration for male and female plaice in annual bottom-trawl surveys of NAFO areas 2J3K (Labrador and NE Newfoundland Shelf), 3Ps (St. Pierre Bank), 3LNO (Grand Bank) and 4T (southern Gulf of St. Lawrence)

\begin{tabular}{|c|c|c|c|c|c|c|c|c|c|c|}
\hline \multirow[t]{2}{*}{ Year } & \multicolumn{2}{|c|}{$2 \mathrm{~J} 3 \mathrm{~K}$} & \multicolumn{2}{|c|}{ 3LNO spring } & \multicolumn{2}{|c|}{ 3LNO fall } & \multicolumn{2}{|c|}{ 3Ps } & \multicolumn{2}{|c|}{$4 \mathrm{~T}$} \\
\hline & Male & Female & Male & Female & Male & Female & Male & Female & Male & Female \\
\hline 1971 & & & 0.61 & 0.62 & & & & & 0.77 & 0.74 \\
\hline 1972 & & & 0.52 & 0.49 & & & & & 0.73 & 0.73 \\
\hline 1973 & & & 0.55 & 0.59 & & & & & 0.68 & 0.66 \\
\hline 1974 & & & 0.58 & 0.51 & & & & & 0.66 & 0.59 \\
\hline 1975 & & & 0.55 & 0.60 & & & & & 0.65 & 0.62 \\
\hline 1976 & & & 0.54 & 0.51 & & & & & 0.66 & 0.62 \\
\hline 1977 & & & 0.60 & 0.57 & & & & & 0.73 & 0.68 \\
\hline 1978 & 0.60 & 0.60 & 0.62 & 0.65 & & & & & 0.83 & 0.71 \\
\hline 1979 & 0.59 & 0.53 & 0.66 & 0.65 & & & & & 0.67 & 0.65 \\
\hline 1980 & 0.61 & 0.58 & 0.62 & 0.63 & & & 0.87 & 0.87 & 0.67 & 0.64 \\
\hline 1981 & 0.72 & 0.70 & 0.57 & 0.53 & & & 0.77 & 0.79 & 0.77 & 0.74 \\
\hline 1982 & 0.78 & 0.74 & 0.64 & 0.58 & & & 0.78 & 0.80 & 0.76 & 0.70 \\
\hline 1983 & 0.77 & 0.76 & & & & & 0.78 & 0.79 & 0.69 & 0.65 \\
\hline 1984 & 0.72 & 0.70 & 0.55 & 0.54 & & & 0.74 & 0.77 & & \\
\hline 1985 & 0.73 & 0.69 & 0.56 & 0.53 & & & 0.89 & 0.90 & & \\
\hline 1986 & 0.67 & 0.67 & 0.60 & 0.54 & & & 0.88 & 0.85 & & \\
\hline 1987 & 0.64 & 0.64 & 0.65 & 0.55 & & & 0.88 & 0.87 & 0.79 & 0.78 \\
\hline 1988 & 0.68 & 0.69 & 0.65 & 0.60 & & & 0.95 & 0.92 & 0.71 & 0.68 \\
\hline 1989 & 0.74 & 0.73 & 0.60 & 0.53 & & & 0.87 & 0.85 & 0.76 & 0.70 \\
\hline 1990 & 0.78 & 0.76 & 0.60 & 0.56 & 0.72 & 0.70 & 0.85 & 0.84 & 0.73 & 0.67 \\
\hline 1991 & 0.73 & 0.70 & 0.54 & 0.58 & 0.66 & 0.66 & 0.85 & 0.84 & 0.71 & 0.63 \\
\hline 1992 & 0.71 & 0.61 & 0.60 & 0.71 & 0.61 & 0.66 & 0.89 & 0.89 & 0.68 & 0.61 \\
\hline 1993 & 0.73 & 0.63 & 0.69 & 0.78 & 0.65 & 0.68 & 0.81 & 0.83 & 0.68 & 0.61 \\
\hline 1994 & 0.78 & 0.69 & 0.69 & 0.77 & 0.70 & 0.72 & 0.89 & 0.90 & 0.69 & 0.60 \\
\hline 1995 & & & 0.73 & 0.80 & & & 0.87 & 0.88 & 0.66 & 0.58 \\
\hline 1996 & & & & & & & & & 0.65 & 0.58 \\
\hline
\end{tabular}


3 populations (although differences between populations only approached significance; Fig. 5). In the recent period, differences between populations were highly significant, reflecting the dramatic increase in the temperature difference between the sexes in the St. Pierre Bank population (Fig. 5).

\section{Sexual dimorphism in growth}

Sexual dimorphism in growth differed among the populations, although the extent of this difference depended on age (ANOVA: population $\times$ age interaction, $\left.F_{24,683}=18.18, \mathrm{p}<0.0001\right)$. Sexual dimorphism in length was slight and did not differ between the populations at Ages 4 and 5 yr (Table 3, Fig. 6). Dimorphism in length increased steadily with age in the southern Gulf population (Fig. 6). At all ages greater than $5 \mathrm{yr}$, sexual dimorphism in the southern Gulf population was significantly greater than in the other 3 populations (Table 3). Dimorphism in length remained slight in these other populations at Ages 6 to 8 yr. However, dimorphism in the NE Newfoundland population increased with age over 6 yr and was significantly greater than that in the Grand Bank and St.
Table 3. Hippoglossoides platessoides. Multiple comparisons of the population effect on the difference between the sexes in length at age. Populations with the same letter are not significantly different ( $p>0.05$ : Tukey-Kramer test). Populations are Labrador and NE Newfoundland (NENF), Grand Bank (GB), St. Pierre Bank (SPB), and southern Gulf of St. Lawrence (SGSL)

\begin{tabular}{|ccccc|}
\hline Age $(\mathrm{yr})$ & NENF & GB & SPB & SGSL \\
\hline 4 & $\mathrm{~A}$ & $\mathrm{~A}$ & $\mathrm{~A}$ & $\mathrm{~A}$ \\
5 & $\mathrm{~A}$ & $\mathrm{~A}$ & $\mathrm{~A}$ & $\mathrm{~A}$ \\
6 & $\mathrm{~A}$ & $\mathrm{~A}$ & $\mathrm{~A}$ & $\mathrm{~B}$ \\
7 & $\mathrm{~A}$ & $\mathrm{~A}$ & $\mathrm{~A}$ & $\mathrm{~B}$ \\
8 & $\mathrm{~A}$ & $\mathrm{~A}$ & $\mathrm{~A}$ & $\mathrm{~B}$ \\
9 & $\mathrm{~B}$ & $\mathrm{~A}$ & $\mathrm{AB}$ & $\mathrm{C}$ \\
10 & $\mathrm{~B}$ & $\mathrm{AB}$ & $\mathrm{A}$ & $\mathrm{C}$ \\
11 & $\mathrm{~B}$ & $\mathrm{~A}$ & $\mathrm{~A}$ & $\mathrm{C}$ \\
12 & $\mathrm{C}$ & $\mathrm{B}$ & $\mathrm{A}$ & $\mathrm{D}$ \\
\hline
\end{tabular}

Pierre Bank populations at Ages 9 to $12 \mathrm{yr}$. Overall, sexual dimorphism in length appeared to be greatest in the southern Gulf population, intermediate (at older ages) in the NE Newfoundland population, and least in the Grand Bank and St. Pierre Bank populations (Fig. 6).
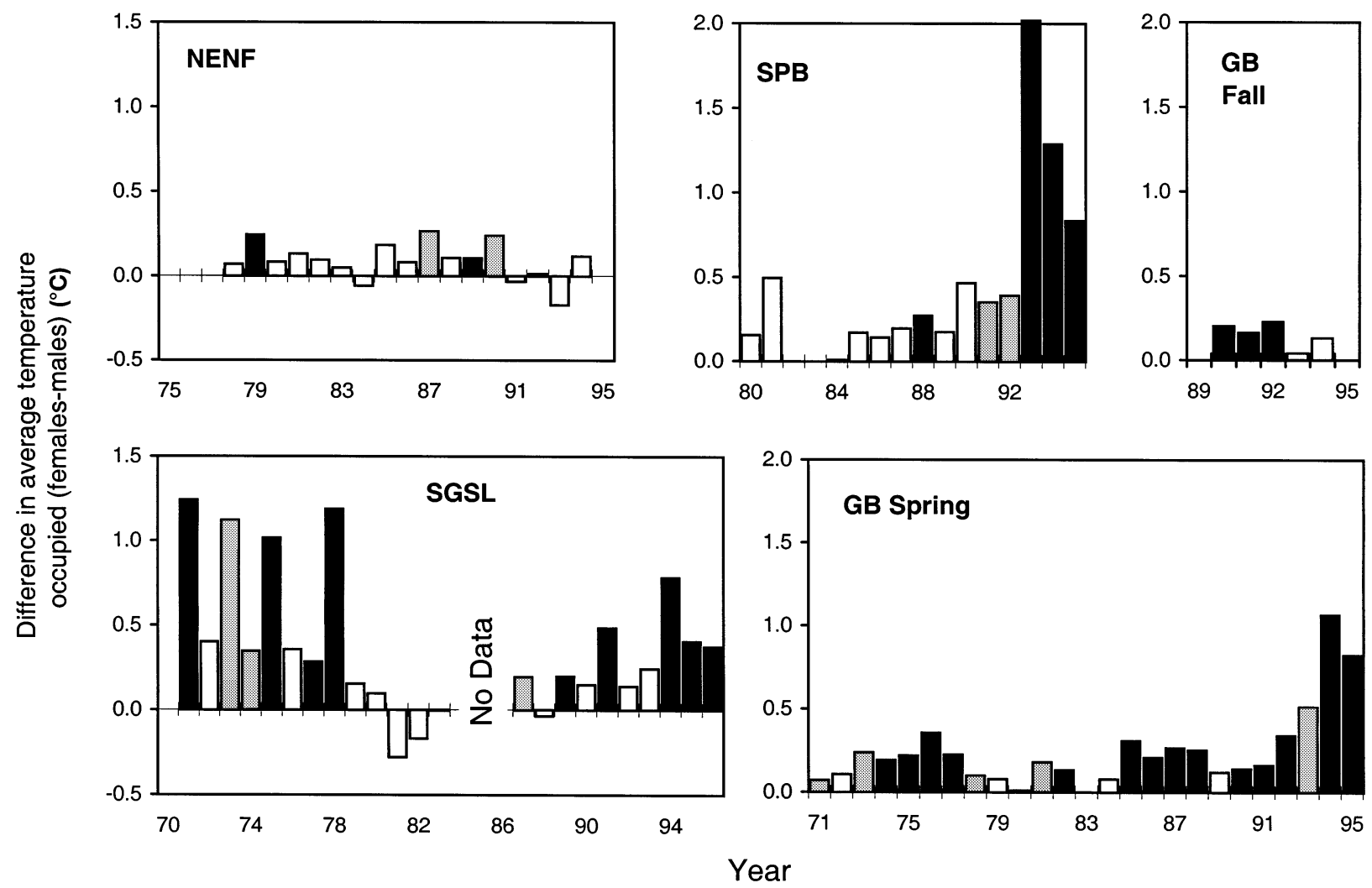

Fig. 4. Hippoglossoides platessoides. Average temperature occupied by females minus that for males. Black and grey shading indicate a significant difference at the 0.01 and 0.05 levels, respectively. Population abbreviations as in Fig. 3 


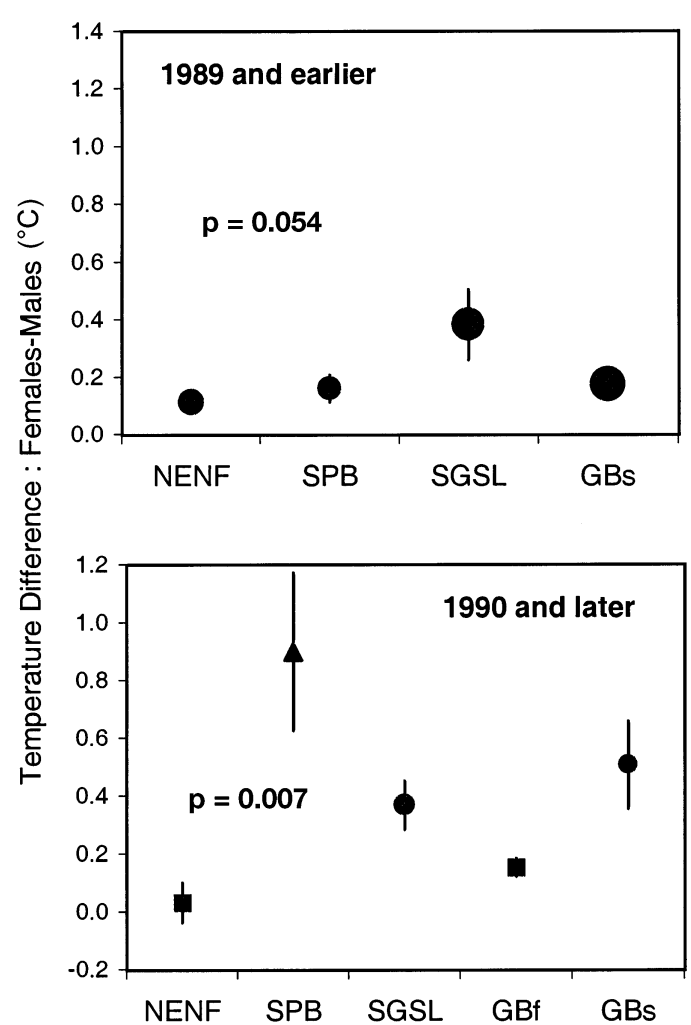

Fig. 5. Hippoglossoides platessoides. Average temperature occupied by females minus that for males for populations in 2 periods. Results for Grand Bank plaice are shown for spring (GBs) and fall (GBf). Symbols show the mean difference in the time period and vertical lines show $\pm 1 \mathrm{SE}$. Symbol size is proportional to sample size (number of years). $\mathrm{p}=$ significance level of the population effect according to ANOVA. Triangle is significantly $(p<0.05)$ different from squares according to Tukey-Kramer test. Population abbreviations as in Fig. 3

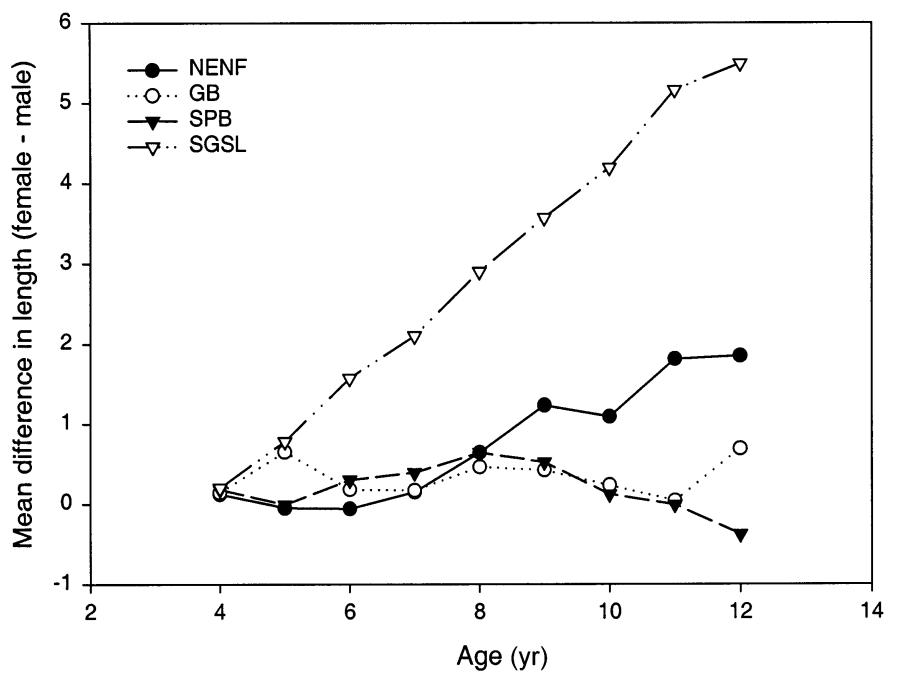

Fig. 6. Hippoglossoides platessoides. Mean difference between the sexes (females - males) in length $(\mathrm{cm})$ at Ages 4 to $12 \mathrm{yr}$ in 4 populations during 1971 to 1995 period. Population abbreviations as in Fig. 3
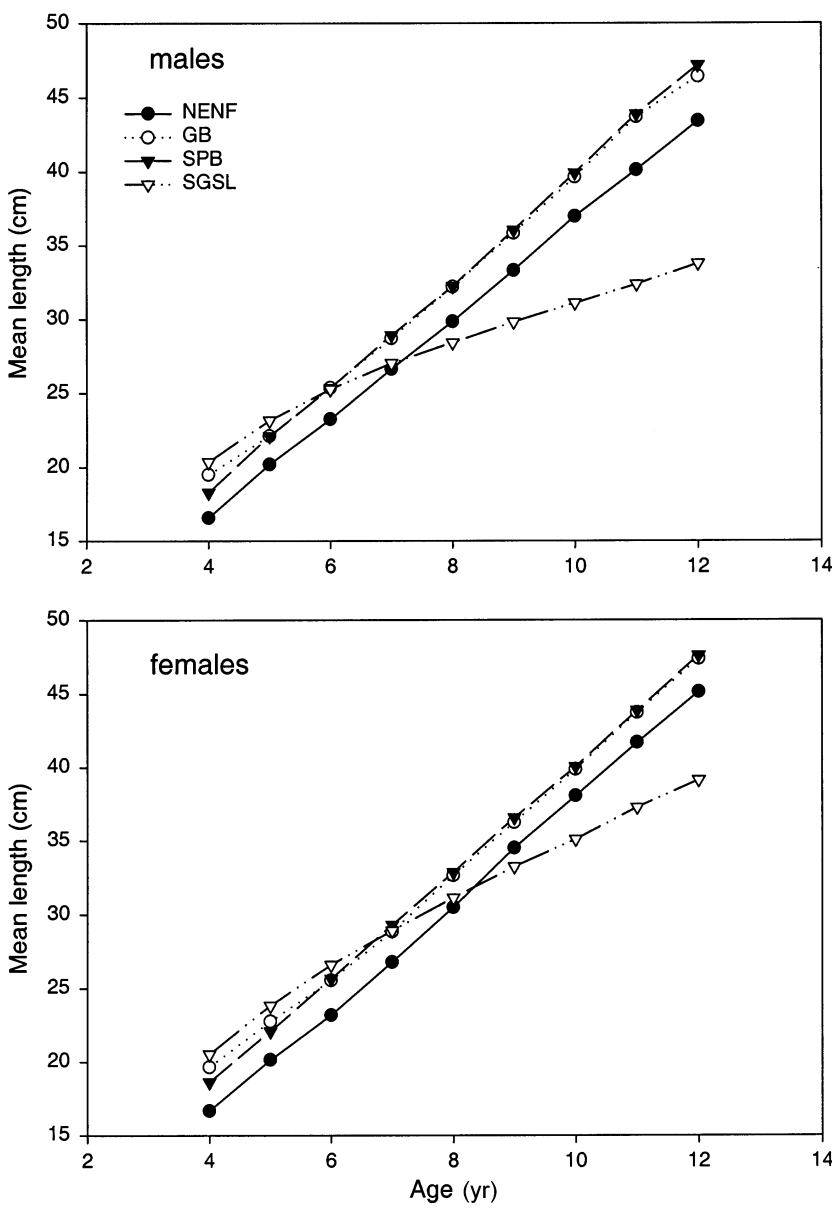

Fig. 7. Hippoglossoides platessoides. Mean length at age for males and females for each population. Population abbreviations as in Fig. 3

The difference between the populations in sexual dimorphism appeared to be associated with differences in growth rate. Lengths at the older ages were greatest in the Grand Bank and St. Pierre Bank populations (Fig. 7), the 2 populations that showed little sexual dimorphism in growth (Fig. 6). The strong sexual dimorphism in the southern Gulf population was associated with an apparent reduction in growth at the older ages, especially in males. The NE Newfoundland population, in which the degree of sexual dimorphism was intermediate, showed intermediate lengths at the older ages. However, in this case, there was no sharp reduction in growth rate at the older ages, as seen in the southern Gulf population; length was smaller in the NE Newfoundland population at all ages examined.

Because the population effect on the difference in temperature distribution between the sexes differed between the periods prior to and since 1990, we also examined sexual dimorphism in length separately for these 2 periods. The main differences between the 2 
periods were an increase in sexual dimorphism in the southern Gulf population and a decrease in dimorphism in the NE Newfoundland population in the later period (Fig. 8). In the later period, dimorphism was greatest in the southern Gulf population and low in all 3 populations off Newfoundland (Fig. 8).

\section{Correspondence between differences in growth and temperature}

The prediction that differences in temperature distribution between the sexes will be greater in populations with stronger sexual dimorphism in growth received some support for the period prior to 1990 but not for the period since 1990 (Fig. 9). In the earlier period, differences between the sexes in both growth and temperature distribution were greatest for the southern Gulf population. Compared to the difference with the southern Gulf population, differences between the Newfoundland populations were relatively slight for both
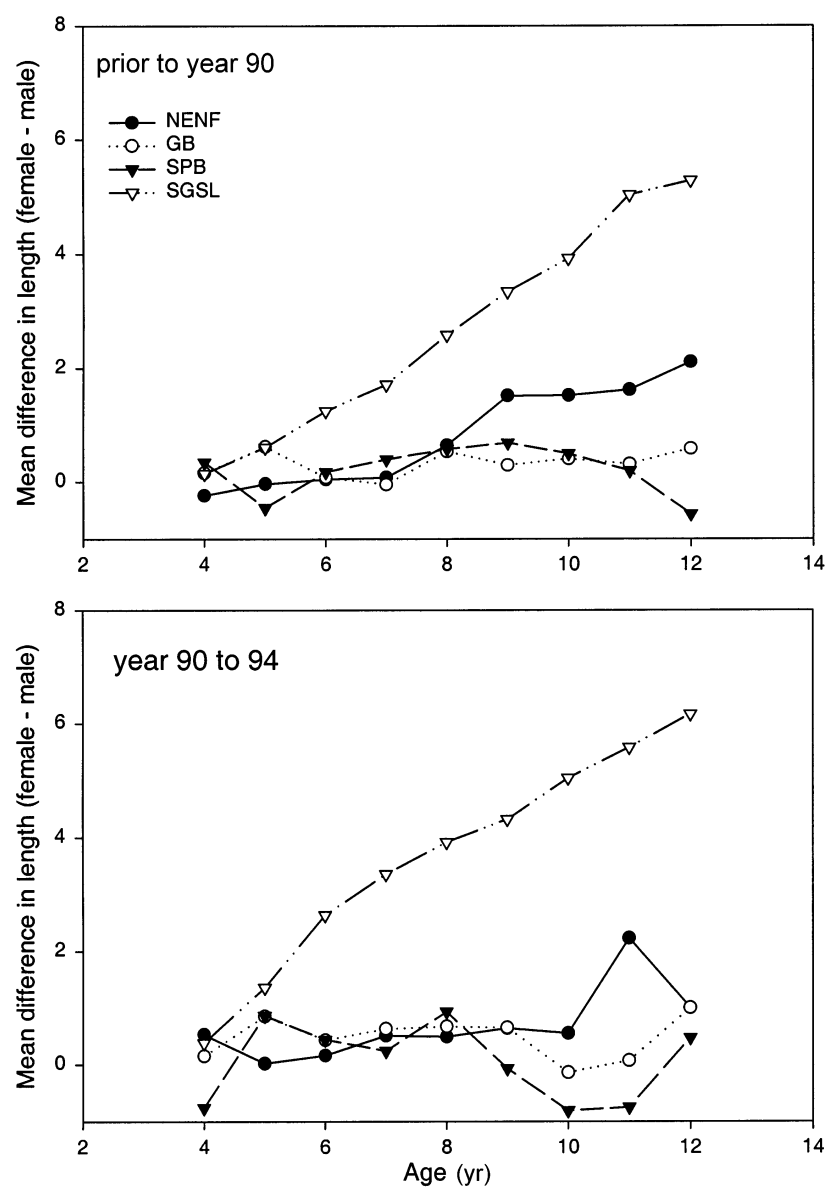

Fig. 8. Hippoglossoides platessoides. Mean difference (female-male) in length $(\mathrm{cm})$ for each stock for the period before 1990 and from 1990 to 1994. Population abbreviations as in Fig. 3

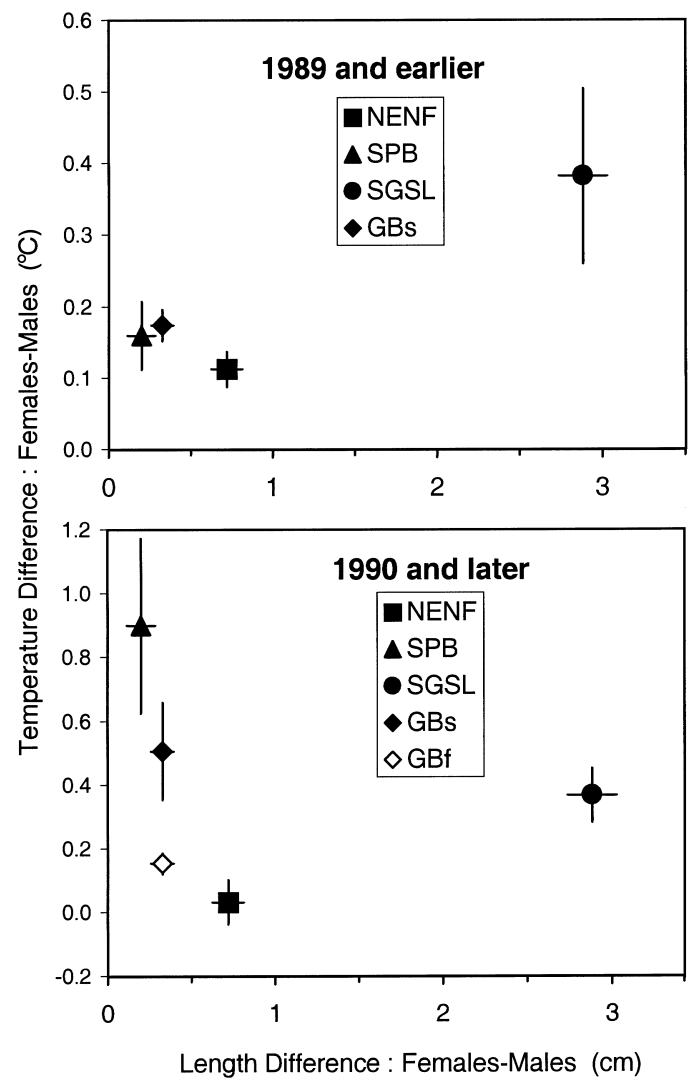

Fig. 9. Hippoglossoides platessoides. Mean difference in average temperature occupied and mean difference in length at age (females - males) for each stock for the period prior to 1990 and for 1990 to 1994. Average size difference for the Grand Bank population in fall is assumed to be the same as that in spring. Population abbreviations as in Fig. 3

length and temperature. However, even in this period, there was not a close correspondence between the length and temperature differences. Dimorphism in growth was somewhat greater in the NE Newfoundland population than in the Grand Bank and St. Pierre Bank populations, but NE Newfoundland plaice did not show a greater difference between the sexes in temperature distribution. In the later period, there was no correspondence between the differences in length and temperature. Both the greatest (St. Pierre Bank) and the smallest (NE Newfoundland, fall Grand Bank) differences in temperature distribution occurred in populations with little sexual dimorphism in growth.

\section{Density-dependent temperature distribution}

The prediction that temperature distribution should be density-dependent, with fish occupying colder temperatures at higher levels of abundance, was supported for the Newfoundland populations but not for 


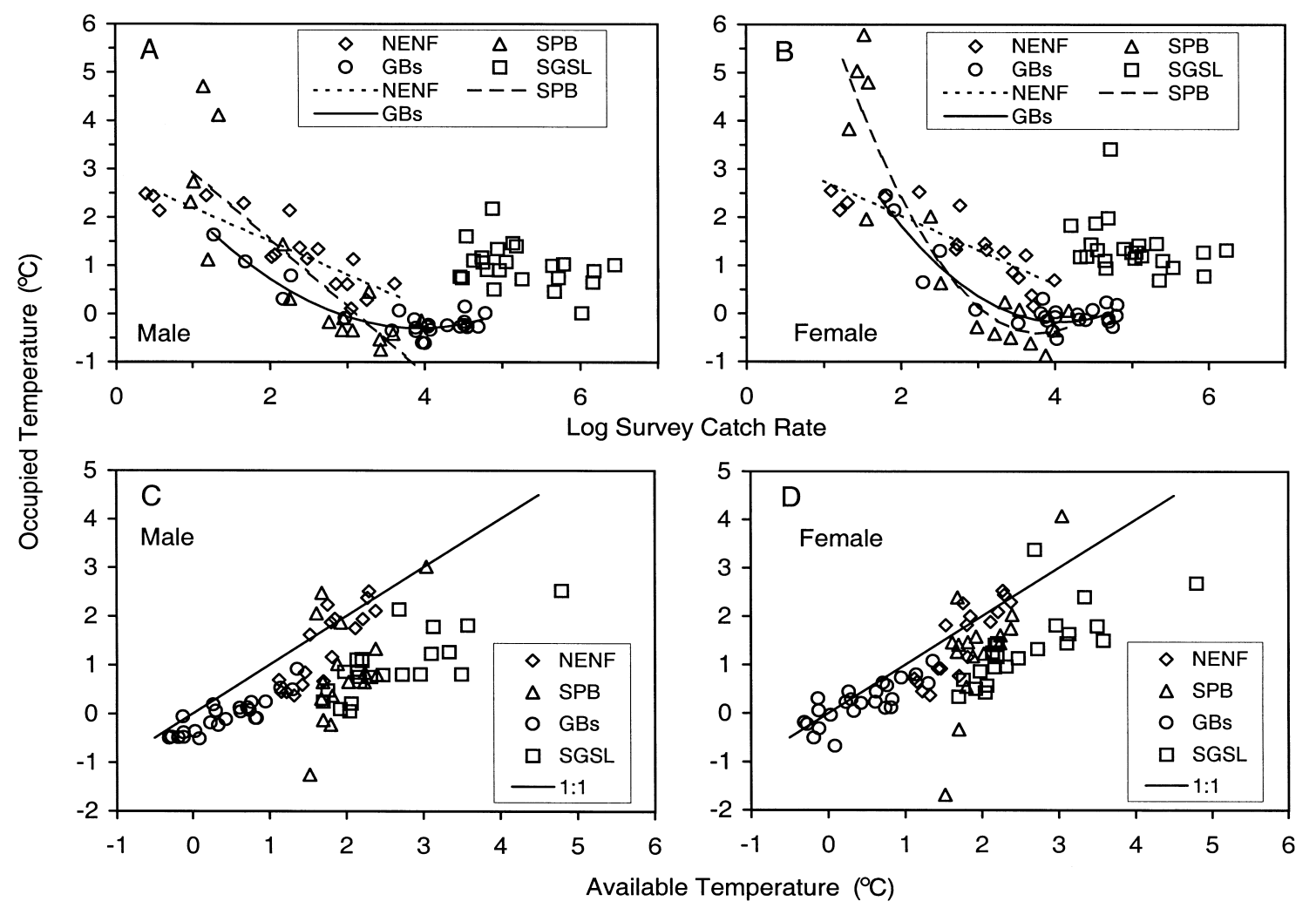

Fig. 10. Relationships between the temperatures occupied by plaice, Hippoglossoides platessoides, and those available to them $(C, D)$ or abundance (A, B). Predicted lines, adjusted to the average available temperature, are shown in (A) and (B) for populations with significant effects of abundance. The identity function (1:1) is shown in (C) and (D). Data points in (A) and (B) are adjusted to the average temperature available in the time series for each population using the coefficients in Table 4; those in (C) and (D) are adjusted to the average relative abundance in each time series. Population abbreviations as in Fig. 3

Table 4. Effects of environmental conditions $(\mathrm{E})$ and relative abundance $(\mathrm{N})$ on the average temperature occupied by Hippoglossoides platessoides in the NE Newfoundland (NENF), Grand Bank (GB), St. Pierre Bank (SPB), and southern Gulf of St. Lawrence (SGSL) populations. E: average bottom temperature available in the survey area; $N$ log $_{\mathrm{e}}$-transformed survey catch rate. Significance levels (p) are 2-sided

\begin{tabular}{|c|c|c|c|c|c|c|}
\hline \multirow[t]{2}{*}{ Effect } & \multicolumn{3}{|c|}{ Females } & \multicolumn{3}{|c|}{ Males } \\
\hline & $\beta$ & SE & $\mathrm{p}$ & $\beta$ & SE & $\mathrm{p}$ \\
\hline $\mathrm{NENF}, \mathrm{n}=17, \mathrm{R}^{2}=0.76$ & & & & $\mathrm{R}^{2}=0.74$ & & \\
\hline E & 1.5712 & 0.2794 & 0.0001 & 1.5749 & 0.2929 & 0.0001 \\
\hline $\mathrm{N}$ & -0.7134 & 0.1238 & 0.0001 & -0.6937 & 0.1216 & 0.0001 \\
\hline $\mathrm{N}^{2}$ & - & - & - & - & - & - \\
\hline $\mathrm{GB}, \mathrm{n}=24, \mathrm{R}^{2}=0.90$ & & & & $\mathrm{R}^{2}=0.92$ & & \\
\hline E & 0.6640 & 0.1511 & 0.0003 & 0.6475 & 0.1006 & 0.0001 \\
\hline $\mathrm{N}$ & -3.7994 & 0.6011 & 0.0001 & -2.1738 & 0.3322 & 0.0001 \\
\hline $\mathrm{N}^{2}$ & 0.4663 & 0.0911 & 0.0001 & 0.2766 & 0.0540 & 0.0001 \\
\hline $\mathrm{SPB}, \mathrm{n}=16, \mathrm{R}^{2}=0.79$ & & & & $\mathrm{R}^{2}=0.62$ & & \\
\hline E & 2.1559 & 0.8325 & 0.024 & 1.3408 & 0.8276 & 0.13 \\
\hline $\mathrm{N}$ & -6.6291 & 2.0781 & 0.0078 & -1.3902 & 0.3182 & 0.0008 \\
\hline $\mathrm{N}^{2}$ & 0.8717 & 0.3751 & 0.039 & - & - & - \\
\hline $\mathrm{SGSL}, \mathrm{n}=23, \mathrm{R}^{2}=0.48$ & & & & $\mathrm{R}^{2}=0.53$ & & \\
\hline E & 0.7077 & 0.1662 & 0.0004 & 0.6457 & 0.1353 & 0.0001 \\
\hline $\mathrm{N}$ & -0.3342 & 0.2258 & 0.15 & -0.2711 & 0.1670 & 0.12 \\
\hline $\mathrm{N}^{2}$ & - & - & - & - & - & - \\
\hline
\end{tabular}


the southern Gulf population (Table 4). For all 4 populations, the effect of relative abundance on temperature distribution was in the predicted negative direction for both sexes. This effect was highly significant in all 6 cases for the Newfoundland populations $(\mathrm{p}<$ $0.01)$, but in neither case $(p>0.10)$ for the southern Gulf population (Fig. 10). Over the observed ranges of densities, the quadratic term for relative abundance was significant in only 3 cases (St. Pierre Bank females, and both sexes on the Grand Bank), most strongly on the Grand Bank, where the range in relative abundance was particularly wide, including both very low and relatively high values (Fig. 10). These regressions indicate a strong inverse relationship between temperature distribution and density when density approaches very low levels (i.e., below about 55 fish/tow) but little effect of density when it varies at relatively high levels.

\section{Effect of environmental conditions on temperature distribution}

The average temperature occupied was also strongly affected by the average available for some populations but not for others (Fig. 10). In all cases, relationships between available and occupied temperatures were in the positive direction (Table 4, Fig. 10). These relationships were highly significant $(\mathrm{p}<0.0005)$ for both sexes in the NE Newfoundland, Grand Bank, and southern Gulf populations but not in the St. Pierre Bank population (Table 4). In the St. Pierre Bank population, the effect of available temperature conditions was significant for females but not for males (Table 4).

\section{DISCUSSION}

The tendency for females to occupy warmer water than males appears to be very widespread in Hippoglossoides platessoides, occurring in all the populations examined. Throughout the 1970s and most of the 1980s, plaice also showed a widespread tendency to occupy cold water relative to that available in the areas surveyed. However, beginning in the late 1980s or early 1990s, dramatic changes in temperature distribution occurred in the populations off Newfoundland, particularly in the Grand Bank and St. Pierre Bank populations in spring. The temperatures occupied by plaice in these populations in spring increased sharply, as did the difference in temperature distribution between males and females. This recent shift toward warmer temperatures was less dramatic in the Grand Bank and NE Newfoundland populations in fall and absent in the southern Gulf population in fall.
Our results provide little support for the hypothesis that differences in temperature distribution between the sexes should be greater in populations with greater sexual dimorphism in growth. Prior to the dramatic changes in temperature distribution in the 1990s, the differences both in temperature distribution and in growth did appear to be greatest in the southern Gulf population. However, even during this time period, there was no tendency for the temperature difference to be greater in the NE Newfoundland population (which showed an intermediate level of sexual dimorphism) than in the Grand Bank and St. Pierre Bank populations (which showed little dimorphism in growth). Following the sharp shifts in plaice distribution in the Grand Bank and St. Pierre Bank spring surveys in the early 1990s, there was no correspondence between the differences in temperature distribution and in length at age.

One reason for this lack of correspondence may be that differences in foraging rate between the sexes are not well reflected by the differences in length at age. Differences in energy intake may also be allocated to differences in condition, activity or reproductive growth. Somatic growth rate is generally expected to decline with maturation in fishes (e.g., Roff 1983, but see Fossen et al. 1999) and differences between the sexes in length at age may reflect differences in maturity schedules. Large changes in age and size at maturity have occurred in the Newfoundland populations from the 1960s to the 1990s (Morgan \& Colbourne 1999), but temporal variation in the maturity schedules of the southern Gulf population has not yet been examined. Further work is required to determine the extent to which the differences in somatic growth between the populations and the sexes reflect differences in maturation rates and in the allocation of energy between growth and reproduction.

Population mean lengths at age will not reflect individual growth rates when mortality is size-selective. For example, Fossen et al. (1999) found that back-calculated growth curves of individual Barents Sea plaice were roughly linear and suggested that the curvilinear relationship observed between mean length and age at capture in this population resulted from size-selective mortality. Fisheries can be a potent source of sizeselective mortality, and fishing pressure appears to have varied substantially between the populations in our study. Exploitation appears to have been lightest for the NE Newfoundland population and heaviest for the Grand Bank population (Bowering et al. 1996, 1997, Morin et al. 1996, Morgan et al. 1997). The extent of size selection by a fishery will depend on growth rates and on selectivity of the fishery as well as on the overall level of fishing mortality. Further work is needed to determine whether differences in mean 
length at age between the sexes and the populations in this study are affected by size-selective mortality.

Any changes in growth in the Newfoundland populations that were associated with their shifts in temperature distribution in the 1990s may not have been well reflected in our index of sexual dimorphism. This index was based on mean lengths at Ages 4 to $12 \mathrm{yr}$ and thus will depend partly on growth in the 1980 s. This may contribute to the lack of correspondence between the differences in growth and temperature distribution in the 1990s.

Another possibility is that the differences in temperature distribution between the sexes may not reflect a difference in food ration. Females may select warmer temperatures than males regardless of food ration. Johansen \& Cross (1980) demonstrated that male guppies, Poecilia reticulata, preferred a lower temperature than females or juveniles, a difference that appeared to be caused by the male androgenic hormone testosterone. However, there is no difference in temperature distribution between the sexes in southern Gulf plaice when they are fasting during the overwintering period (Swain et al. 1998). The existence of a difference in temperature distribution in September when southern Gulf plaice are feeding but not in January when they are fasting suggests that this difference is related to feeding.

A better understanding of the factors underlying differences in growth rate within and between these populations may be needed to illuminate any connection between sex-specific temperature distributions of plaice and sexual dimorphism in growth. In the present study, sexual dimorphism in length was much greater in the southern Gulf population than in the Newfoundland populations. This appeared to be associated with a sharp reduction in growth rate at the older ages in the former population, especially in males. However, sexual dimorphism in the southern Gulf population was just as striking in earlier studies (Powles 1965), when growth rate was much higher, especially for females. Dimorphism also appeared greater in the southern Gulf population than in the Newfoundland populations, particularly the St. Pierre Bank population, in the earlier period (Pitt 1967), when growth in the southern Gulf population was comparable to that in the Newfoundland populations. It is not known why growth in the southern Gulf population has declined or why sexual dimorphism is greater in this population. The populations were sampled with different survey gear, and there is some indication that the gear used to sample the southern Gulf population is better at catching smaller fish (Morin et al. 1996, Morgan et al. 1997). However, this should result in a bigger difference at the younger ages where, in fact, there is little difference in size between the populations.
A number of hypotheses can be suggested to explain the recent shift to warmer waters in the Newfoundland populations. This shift has occurred during a prolonged period of cold bottom temperatures in the Northwest Atlantic. Bottom temperatures over the Newfoundland Shelf were 0.25 to $1.0^{\circ} \mathrm{C}$ below normal from 1986 to 1994, the longest continuous period of negative temperature anomalies since measurements began in 1946 (Colbourne et al. 1997). The shifts in the temperature distribution of plaice involve shifts to deeper waters (Bowering et al. 1996, 1997, Morgan et al. 1997). One hypothesis is that these shifts are a response to the cold conditions of the late 1980s and early 1990s, with plaice moving into deeper water to avoid the unusually cold water on the shelves and banks. However, these movements have not resulted in temperature regulation, maintaining plaice temperature distributions at the levels occupied in the warmer period from the mid-1970s to the mid-1980s. Instead, plaice in the Newfoundland populations have occupied much warmer temperatures during the recent cold period than were occupied throughout the earlier warm period. Moreover, no shift towards warmer waters has been evident in recent years in the southern Gulf area, even though a prolonged period of unusually cold bottom conditions also prevailed in this area throughout the 1990s (Gilbert \& Pettigrew 1997).

Seasonal differences in temperature preference may contribute to the differences among surveys in the extent of the recent shift into warm waters. This shift appears to be much stronger in the spring survey of the Grand Bank than in the fall survey of that area. The other survey showing a dramatic shift by plaice into warmer waters in recent years was the St. Pierre Bank survey, also a spring or late-winter survey. The shift into warmer water was less dramatic in the NE Newfoundland survey, a late-fall/early-winter survey, and was absent in the southern Gulf survey, an early-fall survey. Strong seasonal changes in temperature preference do occur in southern Gulf plaice, with distribution shifting from cold waters in September to warm waters in January (Swain et al. 1998). The seasonal movements of plaice on the Grand Bank have not been as clearly demonstrated. Morgan \& Brodie (1991) found that Grand Bank plaice avoided areas of very low temperature in the winter, and there are some indications from fisheries that these plaice move into deeper (warmer) waters in the winter (Morgan et al. 1999). However, tagging studies have indicated that Grand Bank plaice are rather sedentary (Pitt 1969, Morgan 1996). Swain et al. (1998) speculated that a benefit of the overwintering migration of southern Gulf plaice into warm deep waters may be that these warmer temperatures are required for gonad maturation in time for spring spawning. Perhaps more extensive winter 
migrations into deep warm waters have been required in recent cold years in order to promote maturation of plaice in the populations off Newfoundland.

Another possibility is that the recent shifts in temperature distribution reflect density-dependent changes in temperature preferences (cf. Swain \& Kramer 1995). These shifts have occurred during a period of sharply declining plaice abundance in the waters off Newfoundland, and we observed strong relationships between the relative abundance of plaice and the average temperature that they occupied. Moreover, the relationship was in the predicted direction, with plaice occupying warmer waters at lower levels of abundance. This possibility also provides an explanation for the absence of a temperature shift in the southern Gulf population. Mean catch rates in the southern Gulf survey have not declined to the very low levels seen in the surveys off Newfoundland (Fig. 2). This suggests that densities of southern Gulf plaice have remained much higher than those in the areas off Newfoundland (although differences in catchability may contribute to the differences in catch rates between areas). Thus, in contrast to the areas off Newfoundland, the temperatures occupied by plaice in the southern Gulf may have remained relatively cold because densities of southern Gulf plaice have never fallen to the low levels that result in the high per-capita food resources required to support a distribution in warm waters.

Density-dependent effects on temperature preference are expected only when fish compete for densitydependent resources like food. Thus, the extent of density-dependent shifts in temperature distribution would be expected to vary seasonally if there is seasonal variation in feeding intensity. Seasonal variation in feeding has been studied for southern Gulf, Grand Bank and St. Pierre Bank plaice, and feeding is thought to be much lower in the winter (Powles 1965, Minet 1973, Pitt 1973, Zamarro 1991, J. M. Hanson pers. comm.) Thus, if recent shifts of plaice distribution into warm waters are related to density-dependent effects, seasonal variation in feeding intensity could contribute to the differences observed between surveys in the extent of this shift. The much stronger shift in the spring survey of the Grand Bank compared to the fall survey is consistent with Zamarro's (1991) observation that feeding intensity by plaice on the southern Grand Bank is much greater in spring and summer than in late fall. Likewise, the less dramatic shift into warmer water on the NE Newfoundland Shelf (despite very low abundance in recent years) may be related to reduced feeding intensity in late fall and early winter.

The data reported here support the prediction that, given a sufficiently wide range of densities, temperature preferences should be density-dependent, with distribution shifting toward warmer temperatures at low levels of abundance. However, as in any observational study, we cannot rule out the possibility that the observed correlation between abundance and temperature distribution is spurious. In particular, the recent period of very low abundance in the populations off Newfoundland has also been a period of unusually cold conditions. Because of this close confounding between abundance and environmental conditions, it is difficult to distinguish statistically between an effect of low abundance versus an effect of cold conditions on plaice temperature distribution (although the lack of an effect in the southern Gulf, where recent conditions have been cold but plaice density has remained relatively high, suggests an effect of abundance rather than of environmental conditions). Temperature conditions on the shelves and banks off Newfoundland have moderated since the mid-1990s (Drinkwater et al. 1999), while plaice abundance in these areas has remained very low, so it may soon be possible to distinguish more clearly between these 2 possible explanatory factors.

Acknowledgements. We thank R. Morin for providing length at age data for the southern Gulf population and for helpful discussion, and 3 anonymous reviewers for helpful comments on the manuscript. We also thank the many technical and ship's staff involved in the collection of these data.

\section{LITERATURE CITED}

Bowering WR, Brodie WB (1991) Distribution of commercial flatfishes in the Newfoundland-Labrador region of the Canadian Northwest Atlantic and changes in certain biological parameters since exploitation. Neth J Sea Res 27: 407-422

Bowering WR, Brodie WB, Morgan MJ (1996) Changes in abundance and certain population parameters of American plaice, Hippoglossoides platessoides, on St. Pierre Bank (NAFO Subdivision 3Ps) during 1972-94 with implications for fisheries management. N Am J Fish Manag 16:747-769

Bowering WR, Morgan MJ, Brodie WB (1997) Changes in the population of American plaice (Hippoglossoides platessoides) off Labrador and northeastern Newfoundland: a collapsing stock with low exploitation. Fish Res 30:199-216

Brett JR (1971) Energetic responses of salmon to temperature. A study of some thermal relations in the physiology and freshwater ecology of sockeye salmon (Oncorhynchus nerka). Am Zool 11:99-113

Brett JR (1979) Environmental factors and growth. In: Hoar WS, Randall DJ, Brett JR (eds) Fish physiology, Vol VIII. Bioenergetics and growth. Academic Press, New York, p 599-675

Colbourne E, de Young B, Narayanan S, Helbig J (1997) Comparison of hydrography and circulation on the Newfoundland Shelf during 1990-1993 with the long-term mean. Can J Fish Aquat Sci 54(Suppl 1):68-80

Dagum C (1985) Lorenz curve. In: Kotz S, Johnson NL (eds) Encyclopedia of statistical sciences. John Wiley \& Sons, New York, p 156-161 
Doubleday WG (1981) Manual on groundfish surveys in the northwest Atlantic. Northwest Atl Fish Organ Sci Coun Stud 2:1-55

Drinkwater KF, Colbourne E, Gilbert D (1999) Overview of environmental conditions in the northwest Atlantic in 1998. Northwest Atl Fish Organ Sci Coun Res Doc 99/36

Elliott JM (1975) The growth rate of brown trout (Salmo trutta L) fed on reduced rations. J Anim Ecol 44:823-842

Fossen I, Albert OT, Nilssen EM (1999) Back-calculated individual growth of long rough dab (Hippoglossoides platessoides) in the Barents Sea. ICES J Mar Sci 56:689-696

Fry FEJ (1971) The effect of environmental factors on the physiology of fish. In: Hoar WS, Randall DJ (ed) Fish physiology, Vol VI. Academic Press, London, p 1-98

Gavaris S, Brodie WB (1984) Results of comparative fishing between the 'A. T. Cameron' and the 'Wilfred Templeman' during July-August 1983. CAFSAC (Can Atlant Fish Sci Advis Comm) Res Doc 84/41:1-16

Gilbert D, Pettigrew B (1997) Interannual variability (19481994) of the CIL core temperature in the Gulf of St. Lawrence. Can J Fish Aquat Sci 54(Suppl 1):57-67

Javaid MY, Anderson JM (1967) Influence of starvation on selected temperature of some salmonids. J Fish Res Board Can 24:1515-1519

Johansen PH, Cross JA (1980) Effects of sexual maturation and sex steroid hormone treatment on the temperature preference of the guppy, Poecilia reticulata (Peters). Can J Zool 58:586-588

Magnuson JJ, Crowder LB, Medvick PA (1979) Temperature as an ecological resource. Am Zool 19:331-343

Mahon R, Smith RW, Bernstein BB, Scott JS (1984) Spatial and temporal patterns of groundfish distributions on the Scotian Shelf and in the Bay of Fundy, 1970-1981. Can Tech Rep Fish Aquat Sci 1300

Minet JP (1973) Food and feeding of the American plaice (Hippoglossoides platessoides F) on St. Pierre Bank and on Cape Breton Shelf. Int Comm Northwest Atl Fish Redb Part III 3:59-70

Morgan MJ (1993) Ration level and temperature preference of American plaice. Mar Behav Physiol 24:117-122

Morgan MJ (1996) Preliminary results of tagging experiments on American plaice in NAFO Divs. 3LNO. Northwest Atl Fish Organ Sci Coun Res Doc 96/61

Morgan MJ, Brodie WB (1991) Seasonal distribution of American plaice on the northern Grand Banks. Mar Ecol Prog Ser 75:101-107

Morgan MJ, Colbourne EB (1999) Variation in maturity-atage and size in three populations of American plaice. ICES J Mar Sci 56:673-688

Morgan MJ, Brodie WB, Walsh SJ, Orr D (1997) An assessment of Divisions 3LNO American plaice. Northwest Atl Fish Organ Sci Coun Res Doc 97/60

Morgan MJ, Brodie WB, Bowering WR (1999) An assessment of American plaice in NAFO Div. 3LNO. Northwest Atl Fish Organ Sci Coun Res Doc 99/40

Morin R, Chouinard GA, Forrest-Gallant I, Hurlbut T, Nielsen G, Sinclair A, Swain D (1996) Status of American plaice in NAFO Division 4T, 1995. Can Stock Assessment Secretariat Res Doc 96/70

Nielsen GA (1994) Comparison of the fishing efficiency of research vessels used in the southern Gulf of St. Lawrence groundfish surveys from 1971 to 1992. Can Tech Rep Fish Aquat Sci 1952

Perry RI, Smith SJ (1994) Identifying habitat associations of marine fishes using survey data: an application to the northwest Atlantic. Can J Fish Aquat Sci 51:589-602

Pitt TK (1967) Age and growth of American plaice (Hippo-

Editorial responsibility: Kenneth Sherman (Contributing

Editor), Narragansett, Rhode Island, USA glossoides platessoides) in the Newfoundland area of the Northwest Atlantic. J Fish Res Board Can 24:1077-1099

Pitt TK (1969) Migrations of American plaice on the Grand Bank and in St. Mary's Bay, 1954, 1959, and 1961. J Fish Res Board Can 26:1301-1319

Pitt TK (1973) Food of American plaice (Hippoglossoides platessoides) from the Grand Bank, Newfoundland. J Fish Res Board Can 30:1261-1273

Powles PM (1965) Life history and ecology of American plaice (Hippoglossoides platessoides F) in the Madgalen Shallows. J Fish Res Board Can 22:565-602

Reynolds WW, Casterlin ME (1979) Role of temperature in the environmental physiology of fishes. In: Ali MA (ed) Environmental physiology of fishes. Plenum Press, New York, p 497-518

Roff DA (1983) An allocation model of growth and reproduction in fish. Can J Fish Aquat Sci 40:1395-1404

Rose GA, Leggett WC (1989) Interactive effects of geophysically-forced sea temperatures and prey abundance on mesoscale coastal distributions of a marine predator, Atlantic cod (Gadus morhua). Can J Fish Aquat Sci 46: 1904-1913

SAS Institute Inc. (1990) SAS/STAT user's guide. Version 6, 4 th edn. SAS Institute Inc., Cary, NC

Scott JS (1982) Depth, temperature and salinity preferences of common fishes of the Scotian Shelf. J Northwest Atl Fish Sci 3:29-40

Scott WB, Scott MG (1988) Atlantic fishes of Canada. Can Bull Fish Aquat Sci 219

Swain DP (1997) Sex-specific temperature distribution of American plaice (Hippoglossoides platessoides) and its relation to age and abundance. Can J Fish Aquat Sci 54: 1077-1087

Swain DP (1999) Changes in the distribution of Atlantic cod (Gadus morhua) in the southern Gulf of St. Lawrenceeffects of environmental change or change in environmental preferences? Fish Oceanogr 8:1-17

Swain DP, Kramer DL (1995) Annual variation in temperature selection by Atlantic cod Gadus morhua in the southern Gulf of St. Lawrence, Canada, and its relation to population size. Mar Ecol Prog Ser 116:11-23

Swain DP, Morin R (1996) Relationships between geographic distribution and abundance of American plaice (Hippoglossoides platessoides) in the southern Gulf of St. Lawrence. Can J Fish Aquat Sci 53:106-119

Swain DP Morin R (1997) Effects of age, sex and abundance on the bathymetric pattern of American plaice in the southern Gulf of St. Lawrence. J Fish Biol 50:181-200

Swain DP, Chouinard GA, Morin R, Drinkwater KF (1998) Seasonal variation in the habitat associations of Atlantic cod (Gadus morhua) and American plaice (Hippoglossoides platessoides) from the southern Gulf of St. Lawrence. Can J Fish Aquat Sci 55:2548-2561

Walsh SJ (1992) Factors influencing the distribution of juvenile yellowtail flounder (Limanda ferruginea) on the Grand Bank of Newfoundland. Neth J Sea Res 29:193-203

Wildhaber ML, Crowder LB (1990) Testing a bioenergeticsbased habitat choice model: bluegill (Lepomis macrochirus) responses to food availability and temperature. Can J Fish Aquat Sci 47:1664-1671

Woiwode JG, Adelman IR (1991) Effects of temperature, photoperiod, and ration size on growth of hybrid striped bass $\times$ white bass. Trans Am Fish Soc 120:217-229

Zamarro J (1991) Feeding behaviour of the American plaice (Hippoglossoides platessoides) on the southern Grand Bank of Newfoundland. Northwest Atl Fish Organ Sci Coun Res Doc 91/30

Submitted: January 20, 2000; Accepted: July 27, 2000

Proofs received from author(s): February 27, 2001 